\title{
The Administrative Organization of the Harvard University Library
}

Mr. Williams is assistant to the librarian of Harvard University Library.

$\mathrm{T}$ HE OLDEST AND LARGEST university library in the United States is far from simple in its administrative structure, but, like the institution of which it forms a part, it may be described as having a flexible organization. This article is an attempt to outline the present administrative situation and to indicate the principal alterations that may be made as suitable occasions arise.

Complexity is suggested at the outset by the fact that, as of July I, I 942, Harvard's $4,400,870$ books were divided among seventy-nine units. The main collection of the college library, usually referred to as Widener, contained 44 per cent of the total; 9 per cent were in the fifty-two special libraries that make up the rest of the college library; 2 per cent were in the eight house (dormitory) libraries; and 45 per cent were in the eighteen libraries of professional schools and research institutions. The latter, at Harvard, are known as department libraries. Perhaps the dispersion of books is not quite as extensive as might be thought at first glance, however, since the main collection and six of the largest department libraries account for $8 \mathrm{I}$ per cent of the total, fifteen of the largest libraries make up $9 \mathrm{I}$ per cent of it, and 36 units contain all but 2 per cent of the books in the university.

The office of director of the university library was not created until I910, and before that date there appears to have been no statutory provision governing relations between the libraries of the university. It is now provided:

The university library consists of all the collections of books in the possession of the university. The director of the university library shall be ex officio chairman of the council of the college library; shall visit and inspect the law, medical, business, and other departmental libraries, and be ex officio a member of their administrative committees, and their librarians shall annually make a report to him. ${ }^{1}$

A further step toward coordination was taken in 1937, when the same man was appointed both director of the university library and librarian of the college library. The Statutes provide for the college library as follows :

[The college library] is for the use of the whole university... The general control and supervision are committed to a council appointed annually. It is the duty of the council to make rules for the administration of the college library. Subject to the direction of the chairman of the council [i.e., the director, who is now also the li-

${ }^{1}$ Statutes, No. 15. In the annual Catalogue of the university. 
brarian] the librarian has the care and custody of the college library, superintending its internal administration, enforcing the rules, and conducting the correspondence. ${ }^{2}$

The central unit of the college library is one of thirty-one academic budgetary departments of the university, and the librarian is responsible for drawing up the budget, which goes to the corporation for approval. He appoints all staff members who are paid from this budget, but those employees (fifteen at present) who are officers of the university must be approved by the corporation, and appointments of officers for terms of more than one year múst also be ratified by the overseers.

The College Library Council consists at present of seven members of the faculty plus the director as chairman. It is appointed annually by the corporation and it is customary each year to reappoint six of the members and replace the one who has served longest. In practice, the council is essentially an advisory and legislative body. The rules for administration it has adopted cover only matters that directly affect the public-library hours, borrowing privileges of all classes of patrons, access to stacks, damage to books, fines and penalties. In accordance with the Statutes, it has left "internal administration" to the librarian.

\section{Duties of Assistant}

The assistant to the librarian, who was originally described as the "general assistant," acts also as assistant to the director. Duties of the position have varied with changing circumstances and have included handling correspondence for the director-librarian, representing him in his absence, assigning and supervising N.Y.A.

2 Ibid., No. 16. and Temporary Student Employment Service personnel, compiling statistics, supervising the project for filming foreign newspapers, giving special reference assistance to the director, and performing a good deal of work in connection with extramural activities of the director as an officer of the American Library Association, etc.

Building services are supervised by a member of the staff responsible directly to the librarian. These include the doormen, coatroom attendant, caretakers (who are, however, on the staff of the university maintenance department), dispatch of packages and distribution of mail, and the messenger service between the main collection and other libraries of the university. The same person also supervises the stack employees at present but, in this capacity, acts under the direction of the assistant librarian in charge of reference and circulation.

"Registrar" will probably suggest to most readers a university official whose duties, at Harvard, are handled by the bursar and by various deans. Here, instead, the college library has a registrar in charge of accounts, financial records and payrolls, purchase of supplies, arrangements for repairs and alterations in the building, recording and acknowledgment of gifts to the college library, and photostat and microfilm services. Logic suggests that one person might well be given responsibility for the building services noted in the preceding paragraph as well as for the duties of the registrar. This combination may take place when circumstances permit, and it might prove desirable at that time to transfer gift records and correspondence to the order department. 


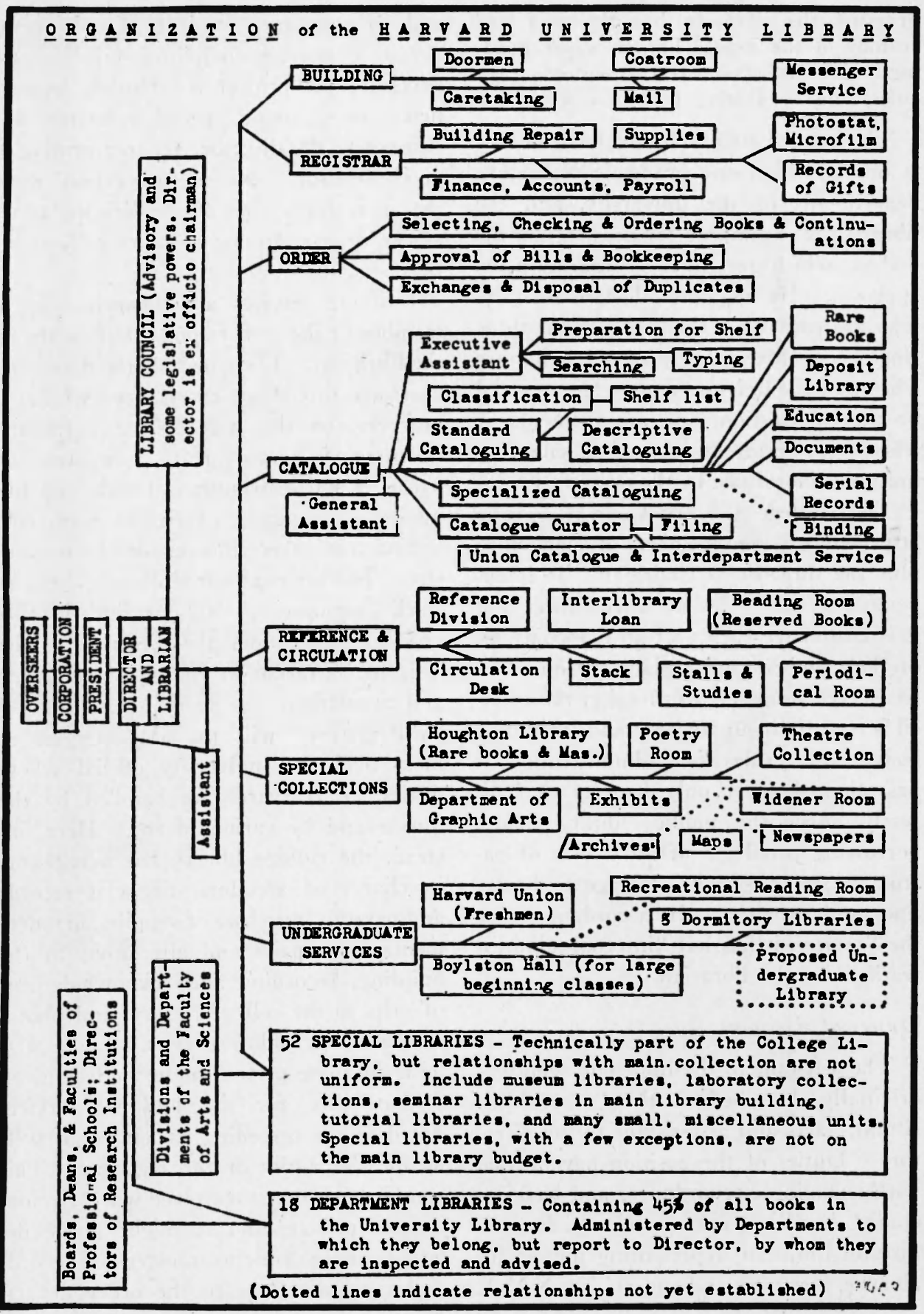


The work of the order department at Harvard falls into three main divisions. One assistant is in charge of selection of books, bibliographical checking, and ordering books and continuations. The book selection problem has been simplified to a considerable extent by the policy of buying everything that appears to be of interest in the fields covered by the college library as soon as it is published in this country and by arrangements for a similarly comprehensive purchase program in England through an agent there.

Another assistant directs the checking and approval of bills, allocation of purchases to the proper fund, and bookkeeping. All books purchased for the main library are paid for from gifts and special endowment funds donated for this purpose, and it is necessary to account for 112 funds. The services of the order department are available for use by all libraries of the university, and at present most of the special libraries and six of the department libraries call upon it to handle all or part of their purchases.

\section{Disposal of Duplicates and Handling of Exchanges}

Disposal of duplicates and handling of exchanges form the third major function of the department. Exchanges are restricted by the fact that the college library has relatively few new or current publications at its disposal for exchange; some of the department libraries have more extensive lists. In recent years the exchange assistant has served as coordinating agent for exchanges throughout the university library.

The catalog department staff includes more than half of the professional employees of the main library and has a relatively more complex organization than the other departments. Table I shows the average number of persons employed in each department, 1939-42, classified according to A.L.A. definitions.

TABLE I

Average Size of Staff, 1939-42

\begin{tabular}{|c|c|c|c|c|c|c|}
\hline & 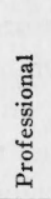 & 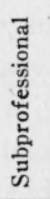 & 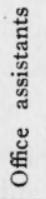 & 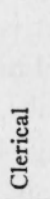 & 岕 & 丞 \\
\hline $\begin{array}{l}\text { Librarian, assistant, and } \\
\text { secretary } \\
\text { Building } \\
\text { Registrar } \\
\text { Order } \\
\text { Catalog } \\
\text { Reference \& circulation } \\
\text { Special collections } \\
\text { Undergraduate services } \\
\text { Special libraries on budget }\end{array}$ & $\begin{array}{r}6 \\
28 \\
7 \\
8 \\
1 \\
2 \\
\end{array}$ & $\begin{array}{r}4 \\
20 \\
4 \\
6 \\
1 \\
1 \\
\end{array}$ & $\begin{array}{l}\text { I } \\
1 \\
2 \\
\text { I }\end{array}$ & $\begin{array}{r}3 \\
3 \\
2 \\
18 \\
14 \\
4 \\
1 \\
\end{array}$ & $\begin{array}{r}2 \\
1 \\
3 \\
3 \\
2 \mathrm{I} \\
\mathrm{I}\end{array}$ & $\begin{array}{l}70 \\
46 \\
19\end{array}$ \\
\hline Total & 54 & $\overline{36}$ & 5 & 45 & $\overline{28}$ & I 68 \\
\hline
\end{tabular}

An executive assistant is in charge of the three activities that occupy the greater part of the clerical and subprofessional personnel-typing, preparation of books for the shelves by marking, labeling, etc., and searching. The latter process consists of checking material with the catalog to discover duplicates, to determine whether or not Library of Congress cards are available, and to note authors' names so that typists can make preliminary cards. The Harvard system calls for checking both purchases and gifts, and the bulk of the material that must be handled is augmented by the buying of large collections en bloc as well as by the fact that from 50 to 70 per cent of all accessions in recent years have come by gift. A record was established last year when 93,000 books were "searched."

\section{Cataloging Divisions}

The standard cataloging division handles descriptive cataloging and classification of ordinary books that do not 
present special problems in handling. Maintenance of the shelflist is a subdivision of the classification section.

The specialized cataloging division catalogs and classifies books difficult to handle, those in Slavic and the minor languages, etc. It is, therefore, a division of specialists. This system formerly prevailed for all books, with an individual subject or language specialist responsible for the classification, subject heading, and descriptive cataloging of all books in his field. Now in this division, that system is retained for the difficult books, but ordinary material can be handled more economically and the work can be more evenly distributed in the standard cataloging division, where classification and subject heading are separated from descriptive cataloging. The subject specialists of the catalog department, it should be added, have always been valuable sources of assistance for the reference and order departments.

The curator of the card catalog supervises the filing staff and is also responsible for maintenance of the union catalog, which includes a depository set of Library of Congress cards as well as cards for books in all units of the university library. It serves, in addition, as the official cata$\log$, since accession information, tracings, etc., are added to cards for books in the main library. The union catalog section includes the interdepartmental telephone service between Harvard libraries, which makes information contained in the catalog readily available throughout the university.

A division with headquarters in the Houghton Library handles cataloging of rare books and manuscripts. Other divisions care for documents and for education, which includes very large collections of textbooks and college catalogs. Selection and transfer of little-used books to the New England Deposit Library, plus simplified cataloging and classification by size for new acquisitions that are sent there directly, occupy another division. Serial records are handled by a division of the catalog department, and the binding records division, now unattached, may be added to the department in the future.

\section{Cataloging for Special Collections}

The department catalogs most of the books added to special libraries of the university as well as all or part of the acquisitions of four department libraries. Four special and two department libraries take advantage of its willingness to supply any Harvard library with copies of cards for all books in the field of the special library that are added to the main collection. In sorting gifts, the catalog department keeps in mind the interests of all collections in the university and passes on appropriate material.

The reference and circulation department, in addition to the activities named in its title, handles interlibrary loans, assignment of stalls and studies, and supervision of the stack employees, the periodical room, and the main reading room, in which are shelved reserved books for all but the largest beginning courses in the college. As will be seen, the reserved book division will eventually be removed from the circulation and reference department if the hoped-for separate undergraduate library is constructed. The present main reading room would remain under the department, but it would then be a general reading room, with space for expansion of the reference collection that is now confined to one end of it. 


\section{Special Collections}

The special collections department is concerned only with those collections that are an integral part of the main library. The chief of these is the former "Treasure Room," which now occupies its own building, the Houghton Library, connected with Widener by a bridge and a tunnel. This building has its own reading room, exhibit facilities, work rooms, offices, and rooms for special collections, as well as space for 250,000 volumes, and it houses most of the rare books and manuscripts of the college library. Naturally it handles its own circulation and much of its own reference work. The rare book division of the catalog department is located in Houghton and is closely associated with the librarians in charge of that building.

All exhibits of the college library theoretically come under the authority of the special collections department, though in practice at present the exhibits in Widener are managed by the assistant librarian in charge of the order department.

The division of printing and graphic arts, which maintains its own special collections and equipment and offers instruction in the subject, has its headquarters in the Houghton building and is under the direction of the assistant librarian in charge.

Two separately endowed special collections in Widener, the theatre collection and the poetry room, have recently become divisions of the special collections department. The Winsor Memorial Map Collection, the Harvardiana and Harvard University Archives Collection (which at present, for physical reasons, serves also as the newspaper reading room), and the Widener Room, containing the remarkable library of fine books assembled by
Harry Elkins Widener, are the other important special collections of the college library. Theoretically they should become divisions of the special collections department, but various considerations make this coordination undesirable at the present moment.

\section{Undergraduate Services}

The department of undergraduate services will be little more than a plan until Harvard can have a separate library building in which undergraduates will not be forced to find their way through a book collection at least twenty times as large as would best serve their purposes. There is now only unified supervision of the freshman library in the Harvard Union, Boylston Hall, which serves the large beginning classes in history, government, and economics, and the house libraries. The latter are collections of from ten to twelve thousand volumes each located in the seven houses occupied (except for the duration) by sophomores, juniors, and seniors, plus a new collection for commuters. They are under joint control of the director and the various house masters; their librarians, usually graduate students, are appointed with the approval of the director, who must also approve their book purchases; but each library does its own ordering and cataloging.

When the undergraduate library is built, it will house the Boylston and perhaps the Union libraries, most of the tutorial collections that will be mentioned later, and a carefully selected undergraduate collection of something less than one hundred thousand volumes, together with its own reference, circulation, and reserved book service. The latter, it has been noted, is now handled in the main 
reading room at Widener and in Boylston Hall. The Farnsworth Room for recreational reading will also come under the new department of undergraduate services.

Harvard's fifty-two special libraries (to be distinguished from the special collections already mentioned and the department libraries treated in the next section of this article) vary in size from one or two hundred books to more than eighty thousand and serve a great variety of needs. Five of them, for freshmen and large beginning classes, have just been mentioned as potential units of the undergraduate library. The proposed new department would also include the eight tutorial collections, relatively small libraries needed by tutors of various subjects in connection with their work.

\section{Seminar Collections}

The main library building houses nine seminar collections covering history, mathematics, and the principal fields of philology and literature. These are open to graduate students who hold keys. Three small temporary collections for research committees, and nine small miscellaneous libraries (for the infirmary, physical education department, medical adviser, etc.) need not be examined here.

Then there are nine laboratory collections ranging in size from 553 volumes for the geographic laboratory to 34,692 for cryptogamic botany and 72,662 for the biological laboratories. It is hoped that construction of a new building will make it possible to combine most of the research materials of the latter two collections, the orchid library, and three department libraries- the Arnold Arboretum, Gray Herbarium, and Museum of
Comparative Zoology-to make a single life sciences library of more than four hundred thousand volumes.

Eight other libraries have functions comparable with those of the laboratory collections: the music library, Isham Organ Library, philosophy, and sociology; and four museum collections, Germanic, Semitic (now being absorbed by Widener), fine arts (in the Fogg Museum), and Dumbarton Oaks Research Collection (Byzantine art) in Washington, D.C.

\section{Service for Professional School}

Finally, the Library of the School of Public Administration (Littauer Center) is unique among the special libraries because it belongs to a professional school rather than to a department under the Faculty of Arts and Sciences. It is the newest of the professional school libraries and its work is on the budget of the main library and under direct administrative control of the librarian of the college. It now houses many of the documents formerly kept in the Widener Building and functions as the document center for the university.

It must be evident by now that the special libraries do not have a great deal in common. They are all, technically, a part of the college library and, with the exception of Littauer, under the control of the Faculty of Arts and Sciences. ${ }^{3}$ It has been seen that most of their order work and cataloging is handled by the staff of the main library, but this does

\footnotetext{
3 Until this year there were, in addition to Littauer, four exceptions to the rule that libraries in dependent of the Faculty of Arts and Sciences were "department libraries," while those under it were "department libraries," while those under it were all of the museums and research institutions except Harvard-Yenching were placed under general supervision of the Faculty of Arts and Sciences. It remains to be seen whether or not this arrangement will be continued after the war.
} 
not distinguish them from all of the department libraries. Fifty-two is, perhaps, a startling number, but it is less disturbing when one considers that some are small office collections, that nine are housed in Widener and thirteen more should eventually be coordinated by the department of undergraduate services, while several others may eventually be combined into collections serving broader fields of knowledge.

\section{Department Libraries}

The eighteen department libraries should, according to the terminology used by most writers on university library administration, be called "college" libraries. Nine of them serve graduate professional schools and the other nine are in research institutions such as observatories and museums. Together they are slightly larger than the main collection of the college library, and the law school library, with 557,753 volumes, is larger than the libraries of many universities.

Two of them are not entirely Harvard property. More than half of the AndoverHarvard Library in the divinity school belongs to the Andover Theological Seminary, which no longer has any legal connection with Harvard, while the ChineseJapanese Library is supported by the Harvard-Yenching Institute, a separate corporation collaborating with both $\mathrm{Har}$ vard and Yenching University. Several of them are not in Cambridge. The Business School is across the Charles River in Boston; the dental and medical schools are several miles farther away; the Arnold Arboretum, Harvard Forest, and Blue Hill Meteorological Observatory are more distant still; and the Astronomical Ob- servatory Library includes a collection located at Bloemfontein, South Africa.

\section{Relationship to Main Library}

All of the department libraries, like most of the special libraries, are financially completely independent of the main library. Under these circumstances it is obvious that a director would encounter great difficulties if he attempted to assume authority over these libraries rather than to make advice and help available to them. Transfers of books between the college library and the department libraries are often arranged, but relationships differ. The school of education, for example, does not attempt to maintain historical research collections but turns older material over to the main collection; the Institute of Geographic Exploration is the university center for current maps and the Winsor Map Collection in Widener confines itself to older material. The librarian of the business school serves as adviser to the college library on purchases in the field of economics, which prevents needless duplication by the main library of material covered by his collection.

\section{Union Catalog}

Maintenance of a union catalog of all university holdings is regarded as the major essential activity in the field of coordination. This work was neglected for several years because of lack of funds, but the lost ground has now been regained and the record is nearly complete. The catalog now also offers telephone reference service which, in combination with a regular system of deliveries between the libraries of the university, makes it possible for any department to locate and obtain books 
quickly from any part of the university.

Only four of the eighteen department libraries depend on Widener for any of their cataloging, and emphasis on maintenance of the union catalog has not been combined with insistence on uniform cataloging. The utility of the union catalog is not impaired by the wide variety of cataloging and classification schemes used throughout the university, and editing by the college library staff takes care of variations in entries. It is much cheaper to do this editing than to require departmental and special libraries to adopt more detailed and technical systems of cataloging than they need.

Many of the departmental and special collections, before they came to the university, were built up by professors as private libraries, and many have continued to be closely identified with individual collectors after becoming Harvard property. Other collections that were begun by the university owe most of their development to the labor of one or more faculty members. It has appeared a sound policy not to dampen or interfere with collecting enthusiasm by insisting on unessential expense or work in keeping records. It is believed that it would be undesirable, even if it were practicable, to impose uniformity on the seventy-nine Harvard libraries; order librarians and catalogers in the central unit could hardly hope to match the interest and the skill in many specialized fields that now go into Harvard book collecting and organization of research materials for use.

\section{Coordinated Decentralization}

Perhaps the essential feature, as suggested at the outset, is flexibility. Individualism naturally brings a certain amount of inefficiency, of unsatisfactory service in units that are too small, of inconvenience for those whose work does not fall wholly within an established field, and of duplication, though the union cata$\log$ makes it possible to forestall much unnecessary duplication and to reduce that which has already taken place. But the middle road of "coordinated decentralization" brings freedom to meet the needs of scholars, to utilize a maximum amount of faculty interest and enthusiasm, and to maintain economical systems of cataloging and records. Harvard administrators are by no means ready to agree with Mr. Branscomb that, as opposed to the often-repeated advantages of centralization, there "is virtually a single argument, the desirability of getting directly at the books needed in one's work." 4

Logical organization might seem to call for appointment of an assistant director who would be responsible for relations with and between the special and departmental libraries. For the present at least, however, there does not appear to be enough work to warrant creation of the position. The staff at Widener, particularly the catalog and order departments, offer their services to all libraries that wish to use them and, when there is a project calling for coordination, such as assembling information for the new edition of the Union List of Serials, it is possible to centralize it under the direction of a member of the college library staff.

\section{Problems of Organization}

There are, of course, good reasons for doubting that a theoretically quite logical administrative organization, either throughout the libraries of a university

4 Branscomb, Harvie. Teaching with Books. Association of American Colleges and A.L.A., I940, p. 134. 
or within the main collection itself, is practicable in any but a new-or totalitarian-institution. As soon as the conditions that gave rise to the original organization have changed, and as soon as relationships are affected by traditions and personalities instead of explicit regulations alone, every feature of the organization involves a good deal more than simple logic, and many changes suggested by logic must be made slowly or postponed to a more suitable time. The danger is that if too little or too late an effort is made to keep the organization changing in the proper direction, it will become hopelessly inefficient and incapable of fulfilling present needs.

The proposed developments mentioned in this paper seem to indicate that the officers of the Harvard library are trying to look ahead and to initiate changes that, in their opinion, will improve the organization of the library. 'They believe that too many of the important department and special libraries have staffs too small to give all-round library service of high quality and that too many of them cover fields so narrow that overlapping is a serious problem. They believe that the solution is development of fewer but larger collections covering related fields of knowledge. One proposed combination of this sort, in the field of the life sciences, has been mentioned. They believe that undergraduate services ought to be detached physically from the main library and have made plans for a separate building which would become headquarters for a department of undergraduate services. They believe that in the past too many minor divisions of the college library have been responsible directly to the librarian. A number of these units have been coordinated in recent years, and the relatively new, still incomplete department of special collections is the appropriate agency to take over most of those that remain.

If the suggested coordination of functions of the registrar and building services also takes place, the general library (with undergraduate and dormitory collections) would then be administered through six divisions. These would include a business office handling finances, records, building, supplies, and special services, and five departments covering order work, cataloging, reference and circulation, special collections, and undergraduate services.

In any case, the administrative organization of the Harvard University Library, after three hundred years, has not ceased to change and to adapt itself to changing environments. This appears to support the hypothesis that it is still alive and reasonably vigorous. 